\title{
PAFAH1B1 Gene
}

National Cancer Institute

\section{Source}

National Cancer Institute. PAFAH1B1 Gene. NCI Thesaurus. Code C75885.

This gene is involved in the modulation of neuronal migration. 